\title{
REVITALISATION OF PROBLEM AREAS AS AN INSTRUMENT FOR SOCIAL AND ECONOMIC ACTIVITY IN THE POLISH MUNICIPALITIES
}

\author{
HENRYK BABIS, ${ }^{1}$ MARCIN JANOWSKI ${ }^{2}$
}

\footnotetext{
${ }^{1}$ Koszalin University of Technology, Faculty of Economic Sciences, POLAND

e-mail: henryk.babis@tu.koszalin.pl

${ }^{2}$ Szczecin University, Faculty of Management and Economics of Services, POLAND

e-mail: marcin.janowski@wzieu.pl
}

RECEIVED
ACCEPTED
JEL
CLASSIFICATION
KEYWORDS

ABSTRACT
10 December 2018

28 December 2018

139

problem areas, revitalisation, social and economic activity, municipality

The regional policy is becoming one of the most important elements in the development policy, in particular regarding the problem areas. The article aims to analyse the rationality of revitalisation of areas threatened with permanent marginalisation, defined as problem areas. The conducted analysis enabled drawing general conclusions and providing recommendations for decision makers. The research method adopted by the authors is secondary research, based on the analysis of data from government sources and literature review.

\section{Introduction}

The sustainable social and regional development requires the participation of smaller cities and rural areas in the development processes. After the political transformation in most of these regions we can observe technical wear and tear of both infrastructure and buildings, in particular residential buildings, as well as adverse demographic and social changes. The phenomena threaten the regions with permanent marginalization. The situation can be 
tackled with integrated revitalization activities which will help to achieve positive results in the social, economic and spatial sphere. Revitalization strengthens the residential, economic and cultural functions, which helps to improve the inhabitants' quality of life. These issues have been analysed in this article. The article also examines synthetically the essence of problem areas and their revitalization by presenting the scope and objectives of revitalization process. As a result it was possible to formulate proposals to create development potential in problem areas. In the article, the deduction and inference methods have been applied.

\section{Problem Areas as Areas of Strategic Intervention}

In many regions, urban and rural areas in Poland, we can observe numerous conditions affecting their development which require directed support in creating the sustainable development of the country. The sustainable economic development of Poland is related to a great extent with innovative regional as well as municipal economy. In numerous regions and municipalities we can observe areas with negative determinants limiting the opportunities for development. These are areas of low development level and limited availability of services. The regions, as areas threatened with permanent marginalization also defined as problem areas, require support in their development processes, which involves e.g. encouraging local communities to be more active, and develop the local unused potential. It will make it possible to develop social potential and boost social innovation.

According to P. Śleszyński research team, the areas threatened with permanent marginalization occurred in Poland in 2016 in 728 municipalities at the area of 104.8 thou. $\mathrm{km}^{2}$ inhabited by 6.1 million people (Śleszyński, Bański, Degórski, Komornicki, 2017). The Strategy for Responsible Development provides that over $1 / 5$ of urban area inhabited by 2.4 million people is subject to degradation processes, and half of them includes old downtown districts (Strategia na rzecz..., 2018). 20\% of urban areas require coordinated activities to counteract this negative phenomenon (www.sejm.gov.pl). Among many reasons for disparities in the development of regions, urban and rural areas, the reference literature indicates mainly historical reasons, i.e. different social and economic situation during the partitions of Poland, unequal development in the interwar period and the period of centrally-controlled economy, as well as the effects of transformation, globalization and European integration (Jak rozwijała się..., 2013). Because of these reasons it is difficult to transform the regions properly, meeting social expectations, which makes these areas lag behind other regions in the country. These regions are most frequently defined as degraded and problem areas, as well as areas of low effectiveness of social and economic, and spatial structures, underdeveloped, poor areas, in need, poorly developed, conflict-prone, endangered, lagging behind others and dilapidated.

These areas are included the national strategic documents, defining the development objectives of the country, regions or municipalities. They include, inter alia:

- Revitalisation Act (Official Journal of Laws, 2015),

- National Revitalisation Plan (Strategia na rzecz..., 2018),

- Guidelines on revitalization in the operational programmes 2014-2020 (Wytyczne..., 2016),

- National Strategy for Regional Development 2010-2020: Regions, Cities, Rural Areas (Strategia na rzecz..., 2018),

- National Spatial Development Concept 2030 (http://mir.bip.gov.pl/strategie-rozwoj-regionalny/17847),

- National Urban Policy 2023 (Strategia na rzecz..., 2018),

- Partnership Agreement - document for programming interventions from the EU funds for 2014-2020,

- Strategy for Responsible Development, 
- regional operational programmes,

- local and municipal revitalization programmes.

The fact that the revitalization of problem areas is included in the abovementioned documents denotes that it is a significant process for the local and regional development. It is emphasized that the activities which aim at implementing the said process affect the economic and social as well as spatial and environmental situation of territorial units.

The Revitalisation Act in art. 9. 1 provides that "the municipality area in decline due to the concentration of adverse social phenomena, in particular unemployment, poverty, crime, low level of education or social capital, as well as insufficient participation in the public and cultural life, can be defined as degraded area, if apart from the above, we can observe in the area at least one of the following negative phenomena:

a) economic phenomena - in particular low level of entrepreneurship, poor standing of local businesses or

b) environmental phenomena - in particular exceeding the standards of environmental quality, and waste which poses a threat to human life, health or environment, or

c) spatial and functional phenomena - in particular insufficient technical and social infrastructure or its poor technical condition, no access to basic services or low quality of these services, inadequacy of planning solutions to the changing functions of the area, insufficient transport services, shortage or low quality of public space, or

d) technical phenomena - in particular technical degradation of buildings, including residential buildings, and non-functioning of technical solutions providing effective use of buildings, regarding in particular energysaving and environmental protection" (Official Journal of Laws, 2015).

Apart from the statutory definition there are also other concepts of defining degraded and problem areas where various criteria are used to identify them (Rakowska, Wojewódzka-Wiewiórska, 2010). In the National Development Strategy 2020 the problem areas as defined as regions which require particular support in their development processes. They are characterised by the highest concentration of adverse development phenomena of national, sub-regional and regional character. It generates low indicators of social and economic development of these areas. The problematic areas include:

- areas of demographic problems,

- areas of social problems,

- areas with low quality of human resources.

The problem areas were defined in the Act on Spatial Planning and Area Development 2030 (Monitor Polski, item 252) which imposed on the Concept of National Spatial Development 2030 an obligation to determine the problem areas.

The problem areas occur in various typologies of the regions which, despite significant diversification, are combined by the fact that they aim to indicate areas of unstable development possibilities. Moreover, attention is paid to the results of cumulated negative phenomena (in particular demographic phenomena) and possibilities and difficulties to solve them (Domański, 1987). The concept of problem areas involves part of geographic area characterized by negative phenomena of social, economic, and technical character, which results in internal anomalies (Zagożdżon, 1988). The problem area is a spatial unit characterised by abnormality of one or more spatial elements (Bański, 2011). Moreover, S. Ciok indicates that to overcome the negative phenomena, the support from outside is indispensable (Ciok, 1994) since the communities struggling with numerous development challenges, 
social and economic issues resulting from the decline of traditional sectors of industry, ineffective economy, sudden decrease in the number of people, social marginalization, permanent poverty, poor infrastructure and poor access to transport and services, require special support.

\section{Areas of Strategic Intervention (OSI)}

The above mentioned descriptions of problem areas indicate that they constitute areas of large concentration of negative development phenomena. The areas which are characterised by these negative phenomena and social issues include most frequently post-industrial areas, neglected districts and industrial dwelling areas, block housing areas which constitute, in the largest cities, a significant share in residential resources, former military areas, and post-mining areas. Limiting the adverse phenomena in these areas requires the intervention of state and regional authorities. Only then will it be possible to fulfil the goal of the EU regional policy, namely struggle to strengthen the social and economic cohesion of the regions. To that end, the areas of strategic intervention (OSI) are established. The provisions of the EU and national strategic documents indicate that one of the priority areas of intervention in the financial perspective 2014-2020 should include cities and urban districts which require revitalization.

The areas of strategic intervention (OSI) have been indicated in the National Strategy for Regional Development 2010-2020: Regions - cities - rural areas (Monitor Polski, 2010, item 423) for the purpose of regional policy. They include the so-called growth poles and problem areas. The document provides that OSI shall meet the following objectives:

a) strengthen cohesion on a national level;

b) increase availability of public transport to voivodship cities within areas of the lowest availability;

c) overcome difficulties related to the location of border areas;

d) restructuring and revitalization of cities and other areas losing their previous social and economic functions;

e) support for rural areas of the lowest access, on the part of inhabitants, to goods and services which condition the development possibilities.

The Act amending the Act on the principles of development policy and some other acts of 24 January 2014 defines the area of strategic intervention of the state as "the area which constitutes the area with concentrated activities related to the development policy focused on territories, including rural areas" (Official Journal of Laws of 2016, item 338). It has also been indicated that the problem area constitutes a special sub-category (Skubiak, Kryk, 2016) and is the area of strategic state intervention where we can identify phenomena unfavourable for its social and economic development and its inhabitants. It has also been indicated that the areas of strategic state intervention, including problem areas, are defined by medium-term strategy for national development, and in compliance with the Act on voivodship self-government (Official Journal of Laws of 1998, No. 91) they are reflected in the strategy for voivodship development. Such wording leaves the decision making process in this respect in the hands of voivodship self-government.

\section{Essence of Revitalization}

The revitalization of degraded areas holds a significant place in the national development policy. It is included in the legal framework resulting from the Revitalisation Act and the Act on planning and spatial development. Under art. 2.1 of the Revitalisation Act, "revitalization constitutes a process which involves recovering the degraded areas from crisis, managed in a comprehensive way, through integrated actions for local communities, public space 
and economy, concentrated territorially, run by stakeholders of revitalization in compliance with the municipal revitalization programme" (Official Journal of Laws of 2015, item 1777). Before 2015, the municipalities conducted revitalization under art. 18 para. 2 p. 6 of the Act on local self-government which, as characteristics of municipal council, indicates „enacting economic programmes”. Until the end of 2023, municipalities can conduct revitalization activities based on revitalization programme, without enacting the municipal revitalization program compliant with the Act. From the beginning of 2024, revitalization must be conducted under the municipal revitalization programme which constitutes the fundamental document scheduling the related activities.

The Act provides that the implementation of municipality own task requires coordination of revitalization plans with the bodies in counties, voivodship and government administration. As beneficiaries, the Act indicates inter alia:

- inhabitants of area under revitalization,

- owners, perpetual usufructor of properties and entities managing the properties within this area,

- entities running or entities which intend to run their business activity within the municipality,

- local authorities and public authorities.

The revitalization of degraded areas, within the meaning of the Revitalisation Act of 9 October 2015, constitutes the municipality non-mandatory own task. It means that not all of the municipalities must implement the revitalization programmes. However, the problems related to degraded areas which constitute barriers for the development of municipalities, including local communities, economies and public space, make municipalities conduct revitalization activities in the degraded areas based on the Revitalisation Act.

Upon indicating the revitalization area (degraded area) the most important is to indicate phenomena resulting from the social sphere which shall occur at all times. The other adverse phenomena from the economic, environmental, spatial and functional as well as technical sphere are supplementary to the social phenomena and indicate the scope and character of degradation which must always include the social element.

The Act provides for the principle specifying that not in every case the revitalization process should be conducted at the same time within the entire degraded area (which may cover even most of the territory of municipality). The area where we can observe particular concentration of adverse phenomena, where the municipality schedules to conduct revitalization activities because of crucial significance for the local development, is determined as revitalisation area. It may cover the entire or part of degraded area, but it cannot be larger than $20 \%$ of the municipalities' area. Moreover, the area cannot be inhabited by more than $30 \%$ people. Both the degraded area and the revitalization area can be divided into sub-areas. Within the revitalization area the municipality can establish a special revitalization zone.

An essential element of all revitalization activities (from the design of activities through implementation and finally the evaluation of completed process), required by law and adopted as a general principle, involves social participation. It means that the revitalization process must ensure active participation of stakeholders through social consultations and established Revitalization Committee. The direct participation of stakeholders aims to increase the knowledge among the municipality inhabitants about revitalization, help them identify with this process and boost motivation related to social commitment. The commencement of social participation processes is one of the priority goals of revitalisation (Programowanie..., 2017).

In order to conduct revitalization activities it is required to:

a) take account of revitalization as essential element of the municipality development overall vision;

b) provide complete analysis to indicate revitalization areas and verify problems including social, economic, spatial, functional, technical and environmental issues; 
c) determine hierarchy of needs regarding revitalization activities;

d) select instruments and interventions properly adapting them to the needs and conditions of particular area;

e) synchronize activities in the social, economic, spatial, functional, technical and environmental spheres;

f) coordinate activities and monitor and evaluate the effectiveness of revitalization;

g) follow the principle of partnership and social participation.

\section{Evaluation of the Previous Resulls of Revitalization}

Between 2007-2013, the expenditure on revitalization projects totalled in all voivodships PLN 8.58 bn, including EU funds in amount of PLN $4.9 \mathrm{~m}$. In the current perspective nearly PLN 7 bn has been planned for revitalization processes (Samorządy..., 2018). For direct support for projects and revitalization activities within the Investment Priority 9b - providing support for physical, economic and social regeneration of deprived communities in urban and rural areas there are resources from the Regional Operational Programmes 2014-2020 in amount of over PLN 5 bn. So far 43\% of the amount has been allocated, i.e. ca. PLN 2.2 bn (www.zmp.poznan.pl). Details are provided in Table 1.

Table 1. Use of financial resources within investment priority (IP) $9 \mathrm{~b}$ in 16 RPO as per the status of 15 March 2018

\begin{tabular}{|c|c|c|c|c|c|}
\hline \multirow{2}{*}{ ROP } & \multirow{2}{*}{$\begin{array}{c}\text { Co - financing agreement } \\
\text { EU Contribution }\end{array}$} & \multirow{2}{*}{$\begin{array}{l}\text { Application for payment } \\
\text { EU Contribution }\end{array}$} & \multirow{2}{*}{$\begin{array}{l}\text { Basic allocation } \\
\text { (MF - limit - PLN) }\end{array}$} & Contracting & Payment level \\
\hline & & & & \multicolumn{2}{|c|}{$\%$} \\
\hline Dolnośląskie & $16,096,820$ & 0 & $289,908,553$ & 5.6 & 0.0 \\
\hline Kujawsko-Pomorskie & 0 & 0 & $211,778,748$ & 0.0 & 0.0 \\
\hline Lubuskie & $96,233,578$ & $2,583,589$ & $125,154,560$ & 76.9 & 2.1 \\
\hline Łódzkie & $648,532,722$ & 491,478 & $699,124,829$ & 92.8 & 0.1 \\
\hline Lubelskie & $70,234,029$ & $35,012,875$ & $453,978,272$ & 15.5 & 7.7 \\
\hline Mazowieckie & $199,231,806$ & $33,099,852$ & $247,036,634$ & 80.6 & 13.4 \\
\hline Małopolskie & $132,897,000$ & $33,224,250$ & $667,858,350$ & 19.9 & 5.0 \\
\hline Opolskie & $90,425,280$ & $1,802,007$ & $104,068,954$ & 86.9 & 1.7 \\
\hline Podlaskie & 0 & 0 & $89,777,182$ & 0.0 & 0.0 \\
\hline Podkarpackie & 0 & 0 & $164,275,424$ & 0.0 & 0.0 \\
\hline Pomorskie & $34,0822,084$ & $22,511,248$ & $328,483,609$ & 103.8 & 6.9 \\
\hline Śląskie & $267,359,192$ & $51,968,400$ & $714,003,927$ & 37.4 & 7.3 \\
\hline Świętokrzyskie & $59,733,389$ & 0 & $195,987,674$ & 30.5 & 0.0 \\
\hline Warmińsko-Mazurskie & $143,667,974$ & $14,610,162$ & $254,150,705$ & 56.5 & 5.7 \\
\hline Wielkopolskie & $112,598,200$ & $28,149,550$ & $333,403,016$ & 33.8 & 8.4 \\
\hline Zachodniopomorskie & 0 & 0 & $156,679,200$ & 0.0 & 0.0 \\
\hline Total & $2,177,832,075$ & $223,453,412$ & $5,035,669,637$ & 43.2 & 4.4 \\
\hline
\end{tabular}

Source: Ocena funkcjonowania ustawy... (2018).

Municipalities have been showing more significant interest in the revitalization programmes. It is reflected in the following data (www.miir.gov.pl):

a) degraded areas determined by the municipality self-government in the enacted revitalisation programmes in 2016 covered the area of ca. 715,813 ha, which constitutes ca. 1/3 of the city area in Poland, inhabited by ca. 3.9 million people, i.e. ca. $29 \%$ of population of municipalities which determined these areas; 
b) municipalities with already developed independent revitalization programme: in 2015 - 255 municipalities, in 2016 - 445 municipalities;

c) municipalities with already enacted programmes: in 2015 - 59 municipalities, in 2016 - 344 municipalities (including 65 under the Revitalisation Act);

d) municipalities working on the revitalisation programme: in 2015 - 354 municipalities, in $2016-1110$ municipalities;

e) social consultations: in 2015 - 116 municipalities, in 2016 - 360 municipalities (under the Revitalisation Act the municipality is obliged to apply at least three (3) forms of social consultations);

f) basic undertakings scheduled within the programmes effectual in 2016 - on average 30 undertakings in GPR.

The evaluation of the course and organization of revitalisation processes in Poland were presented in the substantiation for the draft revitalisation act. It provides that between 2007 and 2013, revitalisation activities were often insufficiently concentrated (in terms of both, issues and territory). The revitalisation was frequently conducted fragmentarily and there was no coordination of activities. The flaws and barriers related to revitalisation activities specified in the substantiation included:

a) frequently observed limitation of revitalisation to the construction process excluding in total or partially the social and economic aspects;

b) lack of consciously determined objectives of conducted activities, preparing the projects without comprehensive analysis of the local situation;

c) use of revitalisation programmes only as instrument used to acquire the EU funds, without defining real activities to improve the situation in problem areas;

d) lack of comprehensive approach in conducted activities, perceiving revitalisation as the construction process, neglecting social factors in preparing and implementing the revitalisation processes;

e) lack of indispensable coordination between public institutions at developing the revitalisation programmes;

f) lack of durability, continuity of revitalisation activities in municipalities (which are often at present developed ad hoc, only when there is a possibility to receive external funds);

g) low level of social participation in the activities when the local revitalisation programmes are developed and projects are prepared, which resulted in low effectiveness of conducted activities related to counteracting the adverse local social and economic phenomena.

The evaluation of revitalisation process also includes the results of inspection conducted by the Supreme Chamber of Control (Najwyższa Izba Kontroli, 2016). The inspection report provides the following conclusions:

a) revitalisation processes in a limited extent contributed to solving the problems of degraded urban areas;

b) by conducting activities scheduled in the local revitalisation programmes (LPR), municipalities failed to obtain the effects of spatial cohesion of conducted projects, eliminate the problematic phenomena and permanently improve the living conditions of the inhabitants in these areas;

c) investment plans included in LPR were implemented only in a limited extent and most often included only single projects which received support in the form of EU funds;

d) no possibilities were provided to enable full participation of local community at developing the programmes and revitalisation projects, which resulted in the lack of common activities between the inhabitants and local authorities; 
e) LPR were not perceived by municipalities as instruments for integrated management of activities performed by entities which could participate in the revitalisation process to achieve the goals, and only as documents which constituted grounds for applying for EU funds;

f) municipalities failed to follow the requirement regarding monitoring the implementation of activities scheduled in LPR. Monitoring was not performed or was inconsistent with the assumptions defined in LPR, and as a result the municipalities had no knowledge on the impact of implemented projects on the fulfilment of assumed revitalisation goals;

g) in the system related to the implementation of financial resources allocated for revitalisation there were no effective mechanisms for evaluating LPR, regarding ensuring by the programmes the results of conducted revitalisation process;

h) municipalities failed to perceive the revitalisation programme as an instrument for managing the activities of all entities operating within the degraded area to obtain best revitalisation results.

\section{Conclusions and Proposals for Changes in the Organization of Revitalisation Processes}

More effective management of revitalisation processes and elimination of the previously specified flaws take on more significance since between 2014 and 2020 revitalisation has been recognized as an important task in the local development policy with allocated financial resources in amount of ca. PLN 25-26 bn.

Managing the revitalisation process within degraded urban areas requires comprehensive and coordinated actions. The condition for obtaining the expected revitalisation results is to take account of social, economic, infrastructural and environmental factors. The correct management of degraded area revitalization processes should be supported to a great extent by the provisions of the Revitalization Act.

The revitalisation programme should be perceived by municipalities as the basic instrument for managing the revitalisation process, which will ensure the completion of activities and fulfilment of revitalisation goals.

In the revitalisation process we shall engage to a greater extent people who are directly related to the revitalised areas, which will exert positive impact on their sense of responsibility for the close vicinity and encourage beneficiaries of the process to create public space as per their needs and expectations. In the process of social participation, more commitment of non-governmental organizations is necessary ensured by boosting direct participation in conducing social activities.

After 2020, access to subsidies from the EU structural funds or other aid resources will be limited and therefore funding the revitalisation projects will be more difficult. More and more often experts indicate that in the future the conduced projects should be profitable and should pay back themselves, and the same time should bring social benefits. Therefore, after 2020 we should initiate more extensive cooperation between local authorities and private sector in the form of public and private partnership. This form has been significantly promoted by the Ministry of Investment and Economic Development as well as organizations supporting such investments.

\section{References}

Bański, J. (2011). Obszar problemowy - koncepcje i kryteria identyfikacji. In: Budowanie spójności terytorialnej i przeciwdziałanie marginalizacji obszarów problemowych. Warszawa: Ministerstwo Rozwoju Regionalnego.

Ciok, S. (1994). Wybrane obszary problemowe Polski Południowo-Zachodniej. Wrocław: Wydawnictwo Uniwersytetu Wrocławskiego. Domański, R. (1987). Przestrzenna organizacja rozwoju regionalnego. Warszawa: Studia KPZK PAN. 
Ekspertyza wykonana na zlecenie Ministerstwa Rozwoju Regionalnego (2010). Warszawa.

http://mir.bip.gov.pl/strategie-rozwoj-regionalny/17847.

Jak rozwijała się polska gospodarka przez ostatnie 150 lat (2013). Retrieved from: https://forsal.pl/artykuly/732064,pkb-polskihistoryczne-rozwoj-gospodarki-przez-150-lat.html.

Koncepcja Przestrzennego Zagospodarowania Kraju 2030 (2018). Retrieved from: http://mir.bip.gov.pl/strategie-rozwojregionalny/17847_strategie.html.

Krajowa Polityka Miejska 2023 (2015). Ministerstwo Infrastruktury i Rozwoju. Retrieved from: https://www.miir.gov.pl/media/11579/ Krajowa_Polityka_Miejska_2023.pdf.

Krajowa Strategia Rozwoju Regionalnego 2010-2020: Regiony, Miasta, Obszary wiejskie (2010). Retrieved from: www.mir.gov.pl/ media/3337/KSRR_13_07_2010.pdf.

Ministerstwo Infrastruktury i Rozwoju (2014). Narodowy Plan Rewitalizacji 2020. Założenia. Retrieved from: www.mir.gov.pl/media/4438/ NarodowyPlanRewitalizacji_Zalozenia_062014.pdf.

Najwyższa Izba Kontroli (2016). Informacja o wynikach kontroli: Rewitalizacja zdegradowanych obszarów miast. Warszawa: Departament Infrastruktury. Retrieved from: https://www.nik.gov.pl/plik/id,11869,vp,14240.pdf.

Ocena funkcjonowania ustawy z dnia 9 października 2015 r. o rewitalizacji - materiał informacyjny (2018). Retrieved from: www.zmp. poznan.pl/uploads/attachment/file/2132/Ocna_funkcjonowania_ustawy_o_rewitalizacji_MATERIA__INFORMACYJNY.docx.

Programowanie perspektywy finansowej 2014-2020. Umowa Partnerstwa (2017). Ministerstwo Infrastruktury i Rozwoju. Retrieved from: https://www.funduszeeuropejskie.gov.pl/strony/o-funduszach/dokumenty/umowa-partnerstwa.

Rakowska, J., Wojewódzka-Wiewiórska, A. (2010). Zróżnicowanie przestrzenne obszarów wiejskich w Polsce - stan i perspektywy rozwoju w kontekście powiązań funkcjonalnych. Warszawa: MRR.

Samorządy mogą pozyskać na rewitalizację prawie $7 \mathrm{mld}$ zł (2018). Retrieved from: www.terenyinwestycyjne.info/index.php/rozmowa-z/ item/11885-samorzady-moga-pozyskac-na-rewitalizacje-prawie-7-mld-zl.

Skubiak, B., Kryk, B. (2016). Tworzenie potencjału rozwojowego obszarów problemowych na przykładzie województwa zachodniopomorskiego. Wrocław: Wydawnictwo Uniwersytetu Wrocławskiego.

Strategia na rzecz Odpowiedzialnego Rozwoju do roku 2020 (z perspektywą do 2030 r.) (2018). Ministerstwo Rozwoju. Warszawa. Retrieved from: https://www.miir.gov.pl/media/48672/SOR.pdf.

Śleszyński, P., Bański, J., Degórski, M., Komornicki, T. (2017). Delimitacja obszarów strategicznej interwencji państwa: obszarów wzrostu i obszarów problemowych. Warszawa: Instytut Geografii i Przestrzennego Zagospodarowania PAN.

Ustawa z dnia 24 stycznia 2014 r. o zmianie ustawy o zasadach prowadzenia polityki rozwoju oraz niektórych innych ustaw. Dz.U. 2014, item 379.

Ustawa z dnia 6 grudnia 2006 r. o zasadach prowadzenia polityki rozwoju. Dz.U. 2016, item 338 with changes.

Ustawa z dnia 5 czerwca 1998 r. o samorządzie województwa. Dz.U. 1998, no. 91, item 576.

Ustawa z dnia 9 października 2015 r. o rewitalizacji. Dz.U. 2015, item 1777.

Uzasadnienie projektu ustawy o rewitalizacji (2018). Retrieved from: www.sejm.gov.pl/Sejm7.nsf/druk.xsp?nr=3594. www.sejm.gov.pl.

Wytyczne w zakresie rewitalizacji w programach operacyjnych na lata 2014-2020 (2016). Minister Rozwoju. MR/H 20142020/20(2)08/2016. Retrieved from: www.funduszeeuropejskie.gov.pl/media/23916/Wytyczne_dot_rewitalizacji_po_aktuali zacji-zatwierdzone02082016clear.pdf.

Zagożdżon, A. (1988). Kilka uwag o obszarach problemowych. Gospodarka przestrzenna, region, lokalność. Biuletyn Komitetu Przestrzennego Zagospodarowania Kraju, 138.

Cite this article aS. Babis, H., Janowski, M. (2018). Revitalisation of problem areas as an instrument for social and economic activity in the Polish municipalities. European Journal of Service Management, 4 (28/2), 17-25. DOI: 10.18276/ejsm.2018.28/2-02. 